\title{
Variability of Transferrin in Three Species of Rodent Populations Coexisting in Farmland
}

\author{
Anna DOBROWOLSKA \& Marek ZAJĄCZKOWSKI
}

\begin{abstract}
Dobrowolska A. \& Zajączkowski M., 1983: Variability of transferrin in three species of rodent populations coexisting in farmland. Acta theriol., 28, 14: 225-233 [With 4 Tables \& 1 Fig.]

It was suggested that the higher frequencies of common transferrin allele in female voles and male mice might indicate different selection in each sex of the two genera (as a result of different reproduction strategies). The increase in heterozygote number causing the decrease in common transferrin allele frequencies were observed during late summer in all three species. The common allele in vole populations occurred more frequently in pasture than in winter corn field. Two investigated species of mice penetrating at the same degree the crops studied did not show the differences in genetical composition dependently to kind of cropfields. The relation between common allele frequencies in particular species and magnitude of average home range size might confirm an effect of dispersal behaviour on gene flow.

[Dept. Vertebr. Anim. Physiol., Univ. of Warsaw, Zwirki i Wigury 93, 02-089 Warszawa, Poland]
\end{abstract}

\section{INTRODUCTION}

The analysis of the interpopulation processes was attempted in long term ecological studies on rodent community occurring in agrocenosis (Adamczewska-Andrzejewska, Bujalska \& Mackin-Rogalska 1979a; 1979b; 1982). Structure of the communities, spatial distribution of individuals as well as strategies of regulation of reproduction and population number was discussed there.

Joining to these studies it seemed to be interesting, if structure and number of population as well as behaviour of particular species may result in variation of transferrin, the polymorphic serum blood protein used as a marker of genetic composition of given species population.

\section{MATERIAL AND METHODS}

The studies were carried out on 104 Microtus arvalis (Pallas, 1779) individuals, 37 individuals of Apodemus agrarius (Pallas, 1771) and 40 individuals of Apodemus

1 Praca została wykonana w ramach problemu węzłowego 10.2.10.03.01 koordynowanego przez Instytut Ekologii PAN. 
flavicollis (Melchior, 1834) caught four time during a year: spring (April), early summer (June), late summer (August) and in autumn (October), in mozaic of fields in Piotrkówek near Niemcza (Lower Silesia, southern Poland). The agrocenosis was formed with alfalfa, pasture, pasture mixture and winter corn fields. Detailed informations on the structure of the agrocenosis examined and ecological description of population studied were given in paper by Adamczewska-Andrzejewska et al. (1982) $M$. arvalis and $A$. agrarius were caught in open field with live-traps (voles and mice) or by flooding the burrows (voles). A. flavicollis were caught in live traps placed in open field and at the border of field and forest.

The blood was taken from retroorbital plexus under ether anaesthesia and than the animals were dissected to determine their sexual activity on the basis

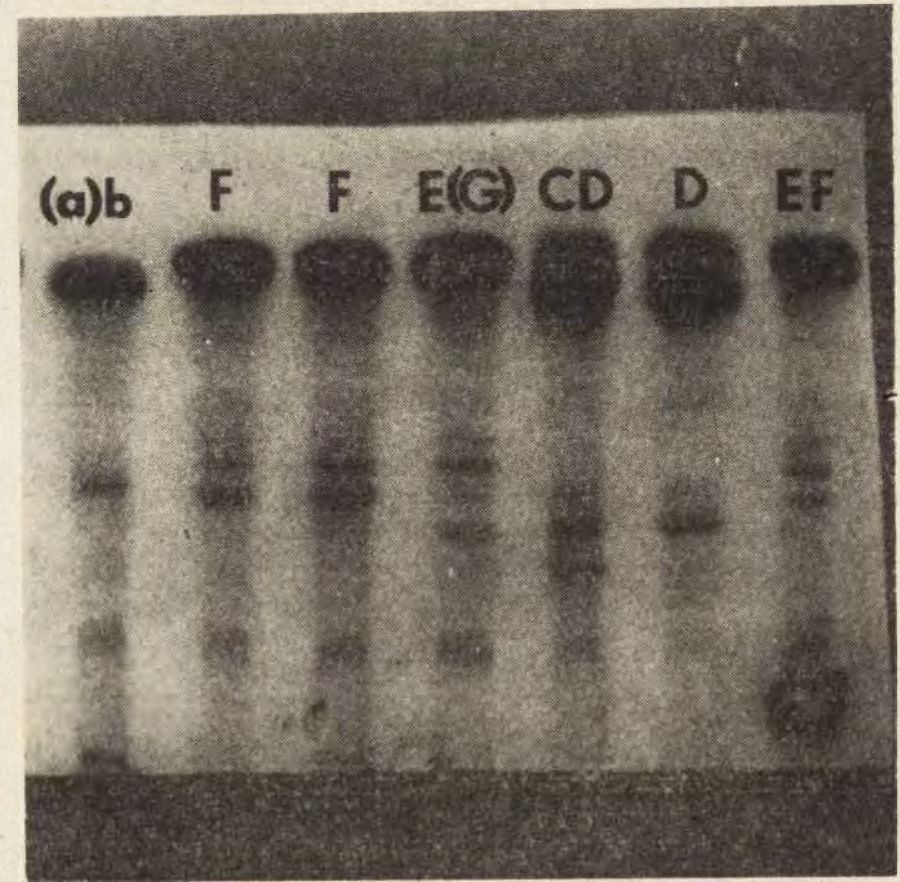

Fig. 1. Electrophoretic pattern of transferrin phenotypes. 1 - Apodemus agrarius, 2, 3, 4, 7 - Microtus arvalis, 5, 6-Apodemus flavicollis.

Other explanations - see in the text.

of morphology of their reproductive organs. The blood was centrifuged and serum was stored at $-5^{\circ} \mathrm{C}$. Starch gel electrophoresis of transferrin was carried out under conditions described by Tomaszewska-Guszkiewicz et al. (1971). For identification of transferrin the method of Mueller et al. (1962) - iron specific staining, was used.

Electrophoretic pattern of $M$. arvalis transferrin region and genetical analysis of allelomorphs obtained are presented in Dobrowolska's paper (1981). Two alleles of single $T f$ locus were distinguished there and the allele nomenclature applied by Maurer for voles (1967) was used.

A. agrarius from fields studied showed the same pattern of transferrin bands as the individuals of the species caught in urban environments (Dobrowolska \& 
Chabros, 1978). Three zones $a, b$, and $c$ were distinguished. It was proved that there was an expression of two alleles $T r f^{a / b}$ and $T_{r f^{c}}$ with zone $(a)$ accompagned the transferrin (b). The nomenclature of alleles follows that recomended by Cohen \& Shreffler (1961) for the transferrin locus in the house mouse, Mus musculus Linnaeus, 1758.

The transferrin bands in A. flavicollis were slower migrating than in two cther rodent species analysed (Fig. 1). The faster zone which migrated paralelly to zone of $A$. agrarius was marked by $C$ and the slower one $D$ according to nomenclature used for genus Mus. These two zone were interpreted as an expression of two transferrin alleles $\operatorname{Tr} f^{C}$ and $\operatorname{Trf}{ }^{D}$ similarly as it was described by Biggers \& Dawson (1971) for transferrin allelomorphs in Peromyscus.

The statistical calculation of the results was made with chi-square-test accepting the differences as statistically significant $(S)$ at $p<0.05$.

\section{RESULTS}

In $M$. arvalis two alleles gave three following genotypes: - homozygote $T f^{E} / F f^{E}$ (rare in population), homozygote $T f^{F} / T f^{F}$ (common in population) and heterozygote $T f^{F} / T f^{F}$. In $A$. agrarius three genotypes were

Table 1

Transferrin genotypes counts in three rodent species inhabiting farmland (pasture mixture, winter corn).

\begin{tabular}{|c|c|c|c|c|}
\hline Species & \multicolumn{3}{|c|}{ Transferrin genotypes } & Chi-square \\
\hline M. arvalis & $T f^{F} / T r^{F}$ & $T f^{F} / T f^{E}$ & $T f^{E} / T f^{E}$ & \\
\hline obs. (exp.) & $90(88.9)$ & $12(14.7)$ & $2 \quad(0,6)$ & $3.71^{1}$ \\
\hline A. agrarius & $\operatorname{Trf} a / b / T r f^{a / b}$ & $\operatorname{Trf} f^{a / b} / \operatorname{Trf} c$ & $T r f^{c} / T r f^{c}$ & \\
\hline obs. (exp.) & $23(23.5)$ & $13(11.9)$ & $1 \quad(1.5)$ & $0.29^{1}$ \\
\hline $\begin{array}{l}\text { A. flavicollis } \\
\text { obs. (exp.) }\end{array}$ & $\underset{7}{\operatorname{Trf} f^{C} / T r f^{C}}$ & $\begin{array}{c}\operatorname{Trf}{ }^{C} / T r f^{D} \\
17(14.9)\end{array}$ & $\begin{array}{c}\operatorname{Trf}^{D} / \operatorname{Trf}^{D} \\
13\end{array}$ & $2.18^{1}$ \\
\hline
\end{tabular}

found: $\operatorname{Tr} f^{a / b} / \operatorname{Tr} f^{a / b}$ homozygote (common in population), homozygote $\operatorname{Trf} / \operatorname{Trf}{ }^{c}$ (rare in population -1 case for 37 individuals and heterozygote $\operatorname{Trf} f^{a / b} / \operatorname{Trf} f^{c}$. In $A$. flavicollis the heterozygotic genotypes $\operatorname{Trf} f^{c} / T r f^{D}$ were the frequent, the homozygotes $\operatorname{Tr} f^{D} / \operatorname{Tr} f^{D}$ were less frequent than previous genotype and homozygotes $T r f^{c} / T r f^{c}$ were rare in population.

The transferrin genotypic proportions in each species studied were tested for confirmity with Hardy-Weinberg equilibrium and exhibited a close agreement (Table 1).

In $M$. arvalis the common allele $T f^{F}$ was more frequent in females than in males while in two mice species the common alleles (A. agrarius - $\operatorname{Trf}^{a / b}$, A. flavicollis - $\left.\operatorname{Tr} f^{D}\right)$ were more frequent in males. However sex differences were not statistically significant (Table 2). 
Table 2

Transferrin allele frequencies in males and females of $M$. arvalis, A. agrarius and $A$. flavicollis (sample size - in parentheses).

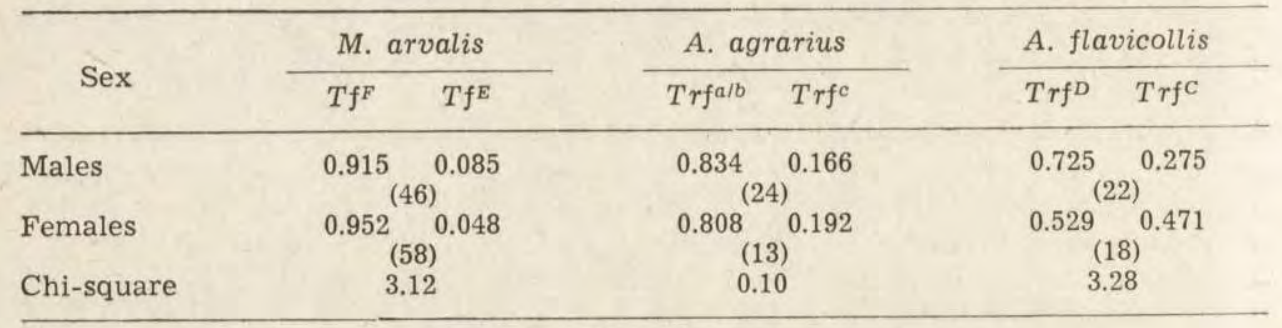

Table 3

Transferrin allele frequencies in $M$. arvalis, A. agrarius, A. flavicollis from different crops (sample size - in parentheses).

\begin{tabular}{|c|c|c|c|c|c|}
\hline \multirow{2}{*}{ Crop } & M. arvalis & \multicolumn{2}{|c|}{ A. agrarius } & \multicolumn{2}{|c|}{ A. flavicollis } \\
\hline & $T f^{F}$ & $\operatorname{Trf} f^{a / b}$ & $\operatorname{Trf} f^{c}$ & $\operatorname{Trf} D$ & $\operatorname{Trf} \mathrm{C}^{\mathrm{C}}$ \\
\hline Pasture mixture & $\begin{array}{c}0.972{ }_{(91)}^{0.028} \\
\end{array}$ & ${ }^{0.789}$ & 0.211 & 0.640 & ) \\
\hline Winter corn & $\begin{array}{c}0.8210 .179 \\
(13)\end{array}$ & 0.853 & 0.147 & 0.600 & 5) 0.400 \\
\hline
\end{tabular}

${ }^{2} p<0.01$

Table 4

Transferrin allele frequencies in $M$. arvalis, $A$. agrarius and A. flavicollis in different seasons (sample size - in parentheses).

\begin{tabular}{|c|c|c|c|}
\hline \multirow{2}{*}{ Season } & M. arvalis & A. agrarius & A. flavicollis \\
\hline & $T f^{F} \quad T f E$ & $\operatorname{Trf} a / b \quad T r f^{c}$ & $\operatorname{Tr} f^{D} \quad T r f^{C}$ \\
\hline $\begin{array}{l}\text { Spring and } \\
\text { early summer }\end{array}$ & $0.970{ }_{(34)}^{0.030}$ & $1.000 \quad 0$ & $0.870{ }_{(8)}^{0.130}$ \\
\hline Late summer & $\begin{array}{c}0.8577_{(18)} 0.143 \\
\text { (18) }\end{array}$ & $0.676{ }_{(17)} 0.324$ & $0.400 \quad 0.600$ \\
\hline Autumn & $\begin{array}{c}0.971 \quad 0.029 \\
(86)\end{array}$ & $0.714{ }_{(7)}^{0.286}$ & $0.591{ }_{(22)}^{0.409}$ \\
\hline Chi-square & $14.87^{2}$ & $4.28^{1}$ & $7.57^{1}$ \\
\hline
\end{tabular}

${ }^{1} p<0.05,2 p<0.01$

The number of individuals of all the three co-existing species permitting in comparison of transferrin allele frequencies were observed in pasture-mixture and in winter corn field. Comparing the frequencies of transferrin alleles in groups of animals living in these two different fields, it was observed that the common $T f^{F}$ allele in $M$. arvalis occurred more frequently in pasture-mixture than in the winter corn field (differences $S$ ). In $A$. agrarius and $A$. flavicollis statistically significant 
differences in frequencies related to kind of farmland were not noted (Table 3 ).

The highest frequencies of common allele were found in $M$. arvalis population and the smallest frequencies in A. flavicollis population were observed (Table 2 and 3 ).

The sample from spring and early summer were taken together due to the small sample size in these seasons. At the beginning or reproduction period the frequencies of the common allele in all species were high $(0.870-1.000)$. They decreased in late summer $(0.400-0.857)$ by increase of heterozygote number and in autumn the frequencies increased again $(0.591-0.971)$ (Table 4). Seasonal changes in allele frequencies were statistically significant in all species studied.

\section{DISCUSSION}

A comparison of electrophoregrams of A. agrarius and A. flavicollis sera showed that these two species have a transferrin band (c) of the same distance of migration. The similarity on the bands in these two species suggested homology of their transferrin locus.

Sex differences in allele frequencies during increase of $M$. arvalis population were reported earlier (Dobrowolska, 1981). They indicated the possibility of the different selection on the transferrin locus in each sex of voles during followed seasons. Presented studies did not confirm the observation, because of the number of genotypes from each season were taken together.

It was interesting that in both mice species studied ( $A$. agrarius and A. flavicollis) although non-significant sex differences in allele frequencies were opposite to that found in $M$. arvalis. It seems possible that higher frequency of transferrin common allele observed in female than male voles and in male than female mice might indicate different selection in each sex in these two genera of rodents. The different way of selection might be due to the strategies of regulation of reproduction and population number in voles being different from those occurring in mice (Adamczewska-Andrzejewska et al., 1979b; Bujalska, 1982).

Seasonal changes in genetic composition of populations studied with decrease of common allele frequencies during summer by the reason of increase of heterozygote number seems to be typical for rodent populations. It may be confirmed that development of the population with the increase in their density (Adamczewska-Andrzejewska et al. 1981) was related to heterozygosity in all species studied. This phenomenon was reported in a lot of studies on demography and genetic 
of small mammal population (Tamarin \& Krebs, 1969; Gaines \& Krebs, 1971; Le Duc \& Krebs, 1975; Lidicker, 1975; Soule, 1976, Smithies, 1978 after Gaines et al., 1978).

The pasture-mixture field was characterised by better trophic condition. Ecological studies by Adamczewska-Andrzejewska et al., (1979a) and Mackin-Rogalska (1982) showed that this farmland being the most frequented by all three studied rodent species. As it was reported by Mackin-Rogalska (1982) the populations of all co-existing species were not spatially isolated and the crops form the common territory. This field observation of interspecies tolerance or even attraction suggested by Adamczewska-Andrzejewska et al. (1979b) is concurred with phenomenon of interspecific adoption in Microtidae and Muridae rodents described by Bisemans \& Bernard (1979).

It seems not accidental that the pattern of frequencies of common transferrin allele in species of rodents studied is opposite to their average home range size (Mackin-Rogalska, 1982) and paralel to number of their population (Adamczewska-Andrzejewska et al., 1982). In the cases of two species studied $-M$. arvalis and A. flavicollis the effect of dispersal behaviour and local environmental differentiation on the structure of gene pools as it was reported by Anderson, 1979; Chitty, 1970; Krebs et al., 1973; Lidicker, 1975; Tamarin, 1978; Krebs, 1979; may be taken into consideration.

$M$. arvalis displayed the highest climbing distribution value the greatest number and the highest frequencies of common transferrin allele (the highest homozygosity). There may be a limitation of gene flow in this species by creating the specific units causing the genic homogenity. A. flavicollis has been viewed by the ethologists as a solitary species (Nikitina \& Merkova, 1963) and its population were recognized as the dispersed social organization. The individuals of this typically forest species may penetrate different environments (field and forest) and move on long distances as it was reported in ecological observations (Adamczewska-Andrzejewska et al., 1982). The lowest frequencies of common transferrin alleles (the highest heterozygosity) in this species were found simultaneously to the greatest average home range size (Mackin-Rogalska, 1982) the highest mobility and the smallest density (Adamczewska-Andrzejewska et al., 1982). It can be suggested that small number stated in $A$. flavicollis population do not limited the gene flow. The low density is compensed by great home range size which might be responsible for maintenance of the polymorphism.

It seems to be important that common transferrin alleles in $M$. arvalis population had an advantage on pasture-mixture field while in $A$. agrarius and $A$, flavicollis the significant advantage in allele fre- 
quencies related to type of crops, was not observed. This fact might be also connected with ethology of the species. The higher frequencies of the common allele in $M$. arvalis on pasture-mixture may be a reflection of adaptation or an expression of preference of this farmland by individuals with common allele. A lack of distinct preference of crop within individuals of $A$. agrarius with common transferrin allele might testify the eqivalence of environments for ths species which may penetrate different environments as the fields, border of forest or as the synurbic species live in urban parks and gardens (Andrzejewski et al., 1978).

Acknowledgements: We should like to thank Dr. K. Adamczewska-Andrzejewska, Dr. G. Bujalska and Dr R. Mackin-Rogalska for their help in blood collection in the field during our joint studies.

\section{REFERENCES}

1. Adamczewska-Andrzejewska K., Bujalska G. \& Mackin-Rogalska R., 1979a: The dynamic of a rodent community in agrocenosis. Bull. Acad. pol. Sci., Cl. II, Ser. Sci., biol., 27: 723-729.

2. Adamczewska-Andrzejewska K., Bujalska G. \& Mackin-Rogalska R., 1979b: The differentiation and spatial distribution of a rodent community in agrocenosis. Bull. Acad. pol. Sci., Cl. II, Ser. Sci. biol., 27: 731-737.

3. Adamczewska-Andrzejewska K., Bujalska G. \& Mackin-Rogalska R., 1982: Changes in numbers of Microtus arvalis (Pall.), Apodemus agrarius (Pall.) and Apodemus flavicollis (Melch.) of chosen crop-fields. Pol. ecol. Studies, 7 [1981]: 175-192.

4. Anderson R. K., 1970: Ecological structure and gene flow in small mammals. Symp. zool. Soc. Lond., 26: 299-325.

5. Andrzejewski R., Babińska-Werka J., Gliwicz J. \& Goszczyński J., 1978: Synurbization processes in Apodemus agrarius population. I - Characteristics of populations in urbanization gradient. Acta theriol., 23: $341-358$.

6. Biesemans W. \& Bernard J., 1979: Un curieux phenomene d'adoption interspecifique chez les rongeurs. Säugetierkundl. Mit., 27: 319.

7. Biggers Ch. J. \& Dawson W. D., 1971: Serum protein polymorphism in Peromyscus of South Carolina. J. Mammal., 52: 376-385.

8. Bujalska G., 1982: Reproduction strategies in populations of Microtus arvalis (Pall.) and Apodemus agrarius (Pall.) inhabiting farmland. Pol. ecol. Studies, 7 [1981]: 229-243.

9. Chitty D., 1970: Variation and population density. Symp. zool. Soc. Lond., 26: $327-333$.

10. Cohen B. C. \& Shreffler D. C., 1961: A revised nomenclature for the mouse transferrin locus. Gen. Res., 2: 306-308.

11. Dobrowolska A., 1981: Serum transferrin polymorphism in common vole Microtus arvalis (Pall. 1779), Bull, Acad. pol, Sci., Cl. II, Ser. Sci. biol., 29: $149-154$. 
12. Dobrowolska A., 1982: Variability of transferrin in Microtus arvalis (Pall.) population inhabiting farmland. Pol. ecol. Studies, 7 [1981]: 257-269.

13. Dobrowolska A. \& Chabros E., 1978: Serum proteins of Apodemus agrarius (Pall. 1785) from different urban environments. Bull. Acad. pol. Sci., Cl. II, Ser. Sci. biol., 26: $337-342$.

14. Gaines M. S. \& Krebs Ch. J., 1971: Genetic changes in fluctuating vole populations. Evolution, 25: 702-723.

15. Gaines M. S., McClenaghan L. R., Jr. \& Rose R. K., 1978: Temporal pattern of allozymic variation in fluctuating populations of Microtus ochrogaster. Evolution, 32: 723-739.

16. Krebs C. M., Gaines M. S., Keller B., Myers J. \& Tamarin R., 1973: Population cycles in small rodents. Science, 179: $35-41$.

17. Krebs C. J., 1979: Dispersal spacing behaviour and genetics in relation to population fluctuations in the vole Microtus townsendii. Fortschr. Zool., 25: $61-77$.

18. Le Duc J. \& Krebs Ch. J., 1975: Demographic consequences of artificial selection at the LAP locus in voles (Microtus townsendii) Can. J. Zool., 53: $1825-1840$.

19. Lidicker W. Z., Jr, 1975: The role of dispersal in the demography of small mammals. [In: "Small mammals: their productivity and population dynamics". F. B. Golley, K. Petrusewicz, L. Ryszkowski, eds]. Cambridge Univ. Press: 173-204. Cambridge.

20. Mackin-Rogalska R., 1982: Spatial structure of rodent populations co-occurring in different crop fields. Pol. ecol. Studies, 7 [1981]: 213-227.

21. Maurer F. W., 1967: Heritability of the plasma transferrin protein in three species of Microtus. Nature, 215: 95-96.

22. Mueller J. C., Smithies O. \& Irvin R. R., 1962: Transferrin variation in Columbidae. Genetics, 43: 1385-1392.

23. Nikitina N. A. \& Merkova M. A., 1963: Ispolzovanie territorii myšami i polevkami po dannym mečenija. Bjul. mosk. Obšč. Ispyt. Prir., Otd. Biol., 68: 15-21.

24. Tamarin C. R., 1978: Dispersal population regulation and $K$-selection in field mice. Amer. Natur., 112: 545-551.

25. Tamarin C. R. \& Krebs C. J., 1969: Microtus population biology. II. Genetic changes at the transferrin locus in fluctuating population of two vole species. Evolution, 23: 183-211.

26. Tomaszewska-Guszkiewicz K., Składanowska E. \& Zurkowski M., 1971: Badania nad polimorfizmem amylazy surowicy krwi bydła nizinnego czarno-bialego w Polsce. Biul. Inst. Genetyki i Hodowli Zwierząt PAN, 24: 5-10.

Accepted, March 14, 1983. 
Anna DOBROWOLSKA i Marek ZAJĄCZKOWSKI

\section{ZMIENNOSC TRANSFERYN W POPULACJI TRZECH GATUNKOW GRYZONI WSPOEWYSTĘPUJĄCYCH NA UPRAWACH}

\section{Streszczenie}

Wykorzystując polimorfizm transferyn przeprowadzono badanie genetycznej kompozycji populacji trzech współwystępujących na uprawach gatunków gryzoni (Microtus arvalis, Apodemus agrarius, A. flavicollis). Zasugerowano, że wyższe częstości stałego allelu u samic nornika, a u samców obu gatunków myszy (Tabela 2) mogłyby wskazywać na różną selekcję u każdej płci badanych rodzajów, jako rezultat różnej strategii reprodukcyjnej stwierdzanej przez Bujalską (1982). U wszystkich trzech gatunków obserwowano wzrost ilości heterozygot powodujący spadek częstości stałego allelu podczas późnego lata (Tabela 4). Common allel w populacjach nornika występował istotnie częściej w grupie osobników $\mathrm{z}$ mieszanki pastewnej niż u tych z oziminy. Dwa badane gatunki myszy penetrujące w równym stopniu badane uprawy (jak stwierdziła Adamczewska-Andrzejewska et al., 1982) nie wykazywały różnic w kompozycji genetycznej w zależności od uprawy (Tabela 3). Przedyskutowano związek pomiędzy częstością common allelu i etologią badanych gatunków gryzoni. Odwrotna zależność między częstotliwością stałego allelu i wielkością średniego zasięgu bytowania, obserwowanego przez Mackin-Rogalską (1982) mogłyby potwierdzać efekt rozproszenia na przepływ genów. 